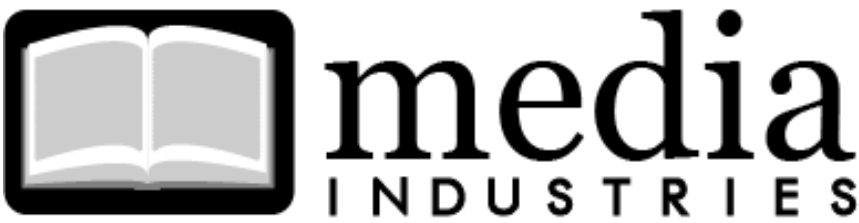

\section{Pamphlets, Commodification, Media Market Regulation, and Hegemony: A Transnational Inquiry into the Seventeenth- Century Print Industry in England, France, and the Netherlands 1}

Pascal Verhoest ${ }^{2}$

Free University of Brussels (VUB)

pascal.verhoest [AT] vub.ac.be

\begin{abstract}
:
Pamphlet history provides early evidence of the mutually constitutive relation of media commodification and political hegemony in the development of parliamentarianism and capitalism. This article traces pamphlets' history in England, France, and the Netherlands. Pamphlets were first developed as a medium for religious and political opposition but were soon recuperated by the ruling classes as a medium of propaganda. As the tensions between vested powers and opposition began to diminish, pamphlets evolved into a more informative and dialogical medium. The regulatory regime of the media, which was at first characterized by repressive censorship, gradually transformed into a market-regulated media regime. Seventeenth-century pamphlets may be considered the first extensively commoditized mass medium in media history.
\end{abstract}

Keywords: Historiography, Political Economy, Regulation, Publishing

Historians have been using pamphlets extensively as a source of information for the study of the late sixteenth, seventeenth, and early eighteenth centuries. However, relatively little attention has been given to the history of the pamphlet as a medium. For most media historians, mass media history only really starts with the advent of the newspaper industry, and pamphlets are generally given only a few cursory references in introductory chapters of textbooks. ${ }^{3}$ This is somewhat surprising given that pamphlets had, by the late seventeenth century, become the most important public print medium in England, France, and the Netherlands. Moreover, they constitute the first significant example of extensively commoditized mass media.

Between 1897 and 2009, five major monographs and two article collections specifically examined the history of pamphlets as a medium in their own right. The countries under study in these works are England, France, and the Netherlands. 4 These publications form the starting 
point for this article and allow the construction of a transnational perspective on pamphlet history. Such a view eases the identification of structural transformation processes in Western European societies, which go beyond medium characteristics and national specificities.

This transnational comparison also confronts the different arguments and findings of the authors under study. Because the literature is still relatively young, some interpretative questions remain unanswered in these historical accounts. For some authors, pamphlets were predominantly a medium of political activism, which in some respects presaged the emergence of a "public sphere." 5 For others, pamphlets were primarily a vehicle for propaganda and manipulation of the public. ${ }^{6}$ Still others emphasize the ways in which the commercial nature of pamphlets influenced their content. ${ }^{7}$

How can a medium that underwent some of the trivializing effects of commercialization at the same time serve as a vital instrument for political information and opinion making? This article argues that the three functions of pamphlets-as a commercial, an emancipatory, and manipulative medium-were mutually constitutive in the transition from a predominantly state-led to a more industry-led media regime. In the process, the regulatory regime of the media transformed from one that was governed largely by coercive means to one that was articulated around a type of hegemonic rule.

This corresponds, in the words of Chantal Mouffe, to an evolution from antagonist to "agonist" relations, which are characteristic of hegemonic regimes. Antagonistic political relations are oppositional relations in which the two sides are enemies that do not share any common ground. Agonism is also an oppositional relation, but the conflicting parties nevertheless recognize the legitimacy of their opponents. ${ }^{8}$

As Conboy observes, "hegemony is not dominance pure and simple but a negotiation between groups in society of unequal power in which those in power manage to retain the overall strategic control while acknowledging partially the aspirations of the subordinate groups." 9 The seventeenth century, in that sense, is protohegemonic, because upcoming religious and political classes used the printed word, not to retain, but to gain, political popular support for this new (hegemonic) worldview.

The seventeenth century was a pivotal century in the countries under study, characterized by the transition from absolute monarchy to parliamentary democracy and from feudal economy to capitalism. It is in this context that a new type of media regime emerged, which forms the foundation of modern media sector organization. These findings thus provide historical evidence that ties the history of commodification of the media to that of political hegemony. ${ }^{10}$

The first section of this article introduces the main features of pamphlets as a medium and as a genre, and of pamphleteering as a political and economic activity. The next three sections review the three facets of pamphlet regulation as a tool of religious and political activism, as a tool of state propaganda, and as a commercial medium. Throughout these sections, the article explains how these aspects influenced the genesis of a new regime for the media. It shows how the monarchy first reverted to censorship in order to silence pamphleteers, and how the monarchy and aristocracy's failure to install a repressive regime of censorship compelled the monarchy and aristocracy to develop the weapon of propaganda. It also demonstrates how the monarchic state forged an alliance with the printing industry in order to control the everincreasing market of oppositional print messages and how, as the relations of power between the ruling classes and the upcoming bourgeoisie relaxed, market forces became more 
predominant in regulation of the media.

\section{Pamphlets in Brief}

Pamphlets can be described as booklets written in the vernacular and printed cheaply on a limited number of quarto pages. These characteristics are important for understanding the political functions of the pamphlet. The quality of typography, paper, and ink were often mediocre and contributed to keeping them affordable. Most importantly, following the example of the religious Protestant tracts of the sixteenth century, pamphlets were generally written in the vernacular in order to reach the widest possible audience. In addition, the cheap production techniques reduced lead times, allowing for quicker responses to political events and the outputs of pamphleteers from rival political or religious factions. ${ }^{11}$

Burke and Briggs note that only a minority of people could afford pamphlets and were sufficiently literate to read them. ${ }^{12}$ However, pamphlet historians have demonstrated that their reach extended far beyond this primary audience. They were distributed widely through a dense network of shops and stalls, and through a network of ambulant retailers, which could easily be expanded in times of political insecurity when sales were high. ${ }^{13}$ In addition, a large secondary readership existed because pamphlets were distributed among friends, sent to correspondents, and referred to in letters. Moreover, a wide tertiary audience existed because pamphlets were also read aloud, listened to, and discussed in private and in public, in places like church porches or taverns. ${ }^{14}$

Two types of pamphlets may be distinguished based on their function: first, political and religious pamphlets, and second, pamphlets of topical interest, which often centered on dramatic themes such as battles, disasters, or disease. The latter have not received much scholarly attention, although they merit deeper analysis. They present an image of pamphleteering very different from the one offered by pamphlets of enlightened artists, philosophers, and politicians. Some of these pamphlets may be interpreted as early articulations of a public sphere theory and have received ample attention in historiography. ${ }^{15}$

The latter are undoubtedly of great historic and political significance. They certainly contributed, to use Sommerville's words, to the development of a new discourse that replaced a fundamentally religious culture whose main text had been the scriptures. However, it is also important to realize that the old scripture texts were not replaced by these pamphlets' formal accounts of reality. Most of these pamphlets created a distorted image of the world, not least because the market was flooded with pamphlets of a commercial nature that fulfilled a demand for printed material dealing with matters of common interest. ${ }^{16}$

The commercialization of print and the trivialization of its content, however, did not undermine its political significance. Politicians and pamphleteers employed different popular literary strategies and media outlets to appeal to the masses and to gain popular support. This included the use of popular literary styles and genres borrowed from oral as well as scribal tradition. Pamphlet literature therefore cannot be understood without reference to folk culture and popular culture. ${ }^{17}$

Raymond, for example, points to the influence, among other genres, of rogue literature on pamphleteering in England. Rogue literature is a commercial form of print that spanned most of the sixteenth century and consisted of moralizing accounts about a criminal underworld in which the boundary between fact and fiction is knowingly distorted. According to Raymond, 
the authors of these tracts "stole pennies from the vulgar by the misuse of ink" and thus offered "a parable of the commodification of print."18 The influence of rogue literature as a popular genre on political and religious pamphleteering was threefold. First, they were quasi-fictions written in an accessible language. Second, they offered entertainment to a large audience. And third, they combined fiction and other literary devices for the purpose of moralizing and social transformation. ${ }^{19}$

Consequently, the informational value of political and religious pamphlets, particularly in early pamphlet history, was relatively low. Their main purpose was to mobilize public opinion for a cause; factual accuracy was subordinate to this aim. Political pamphlets used a great variety of literary genres for this purpose. These literary genres drew heavily on the traditions of oral, visual, and scribal culture that preceded it: poetry, song texts, fables, allegories, dialogues, and satire. ${ }^{20}$ Some pamphleteers also used visual elements, such as typography and images, which contributed to bring pamphlets within reach of still larger audiences. ${ }^{21}$

In order to understand how pamphleteering worked, it is thus necessary to look at the media environment in which these materials were introduced. Pamphlets emerged in an environment dominated by manuscript, oral, and pictorial media. The introduction of print media profoundly changed this media landscape. During its history, the culture of political pamphleteering underwent a series of transformations. Political writing and journalism became more predominant, but the boundaries between genres remained highly permeable. For a long time these different media continued to coexist and had an influence on each other, both in literary form and function. ${ }^{22}$

In the late sixteenth and early seventeenth centuries in particular, the tone of these pamphlets was often seditious, and frequently slanderous, sometimes veering toward vulgarity..$^{23}$ There is little doubt that the style of these pamphlets correlates with the pecuniary motives of their authors. ${ }^{24}$ News, Pettegree observes, became part of an entertainment industry. ${ }^{25}$ That observation should not, however, lead to the conclusion that all pamphlets were a form of political pulp and that all pamphleteers were only motivated by greed, although many, if not most, pamphlet authors had commercial imperatives.

As will be elaborated, the commodification of pamphlets was necessary to pay for their production and distribution costs. The use of literary forms, in turn, reflected not only an attempt to increase sales, but also often the author's desire to influence, if not conquer, the public. ${ }^{26}$ The following paragraphs will demonstrate how this evolution reflected more profound changes in a society that was gradually evolving from absolute monarchy to parliamentary democracy - from a coercive to a hegemonic regime-and in which authorities had to learn how to deal with the mobilization of the public by competing political interests.

\section{Censorship}

The origins of pamphlets are closely connected with religious struggle. On this point the history of pamphleteering in France, the Netherlands, and England is very similar. Protestant, Calvinist, and Anglican churches used polemical pamphlets intensively in their struggle against Rome. ${ }^{27}$ Briggs and Burke therefore conclude that the inevitable countermeasures, namely propaganda and censorship, were "religious before they became political." 28

Pamphlets were inspired predominantly by religious themes in the late sixteenth and early seventeenth centuries. The development of the "institutions of propaganda and censorship" 
were therefore closely connected with the religious conflicts of that time. However, such conflicts were most often intrinsically political ones that not only opposed upcoming and ruling classes but also divided different factions of the ruling classes. ${ }^{29}$

Until the seventeenth century, the discussion of political affairs was ruled by secrecy and was reserved for the privileged, in principle at least. ${ }^{30}$ Even the act of reading news by the common people was regarded as subversive by secular and Catholic authorities, who saw it as encouraging ordinary people to criticize the government. ${ }^{31}$ It is therefore not surprising that the authorities resented the publication of pamphlets. As Harline observes, pamphlets reached an audience larger than the political elite, an audience that was neither capable nor trustworthy enough to discuss political matters. Access to the press therefore had to be restricted. ${ }^{32}$

In the beginning of the seventeenth century, the authorities sent some pamphleteers to the scaffold in order to silence their voices. This was not common practice, but political pamphleteers always risked prosecution. Many oppositional authors, printers, and publishers therefore preferred to run clandestine operations in order to be able to express their opinions. The most seditious books were printed clandestinely, without reference to author, printer, or publisher. ${ }^{33}$ In France, for example, during the period of the Fronde (1648-1653), it is estimated that one out of two libels was a clandestine publication. ${ }^{34}$ The anonymity of print afforded some protection against reprisal and thus provided an opportunity for the expression in public of political ideas that would have been censored otherwise. ${ }^{35}$

This was certainly the case in the French and English monarchies. A different situation presented itself in the Netherlands. The revolt against the Spanish occupation and subsequent installation of the Dutch Republic in the sixteenth century brought with it a decentralized form of government, which rendered a more complicated form of control for pamphlets than in France or England. Moreover, different regulations existed in the different provinces, with some more tolerant than others. ${ }^{36}$

The differences between countries notwithstanding, the history of censorship in the seventeenth century can be summarized as a number of successive waves of repression. Each period of political, religious, or international tension led to an increase in demand for and production of pamphlets. Because pamphlets were considered a weapon of disorder, the authorities reacted by prompting the censors to apply the existing rules more rigorously. ${ }^{37}$

More often than not, legislation lagged behind reality, requiring authorities to continually adapt it to the changing conditions of the market. Repression, although generally ineffective, was the first line of defense. First, pamphleteers were motivated and inventive and, as noted, many pamphlets were published anonymously, clandestinely printed, or imported from abroad -in particular from the Netherlands, which had the most tolerant "mercantile" printing regulation. Second, law enforcement had other higher priorities and there were insufficient resources and staff to police pamphlet production and distribution. Third, depending on the ruler and the circumstances, pamphlets were tolerated better during some periods than in others, particularly in England, and even more so in the Netherlands. ${ }^{38}$

Because repression proved to be an ineffective enforcement mechanism, authorities sought to control pamphlets though a licensing system. They granted printers, who also generally acted as publishers, a license to print on condition that they would not infringe on the rules established by the censors. It was their duty to ensure that heretical, inflammatory, and slanderous material would not be printed. ${ }^{39}$ At first, the English book trade was content to 
collaborate with government in order to secure a relatively stable income. ${ }^{40}$ This also made it relatively easy to regulate their outputs. While in the Netherlands, for example, the guild of printers and booksellers insisted on the clarification and rationalization of the licensing system and contributed to its reformulation. ${ }^{4}$

However, printers were neither able nor always willing to police their colleagues effectively. ${ }^{42}$ This indicates that, as representatives of the emerging entrepreneurial and political classes, they often sympathized with the causes defended by pamphleteers and chose to disobey the law. Furthermore, the legislation left room for the patronage and protection of pamphleteers by political grandees who wished to promote their personal or political causes. ${ }^{43}$ In England, Parliament further promoted the use of double standards in the application of legislation, particularly in the period of 1640-1649, when members frequently breached their own legislation by invoking their parliamentary privileges to publish their speeches and pervert the course of justice by protecting favored authors. ${ }^{44}$

In summary, political battles were increasingly being fought in the public arena, indicating the gradual decline of the coercive regime of the old, absolutist monarchs and the emergence of a new form of political rule. At first, absolutism regarded open religious and political communication and debate as undesirable. It used its prerogatives to adapt censorship rules and laws to the new medium. However, because authorities found these regulations to be unenforceable and lacked the resources to police the printing sector, they tried to align the printing industry with the aims of the state through a licensing system. Thus, the aim of these state-granted monopolies and privileges in printing was, as Starr notes, the alignment of the publishing trade with the aims of the state. ${ }^{45}$ As Peacey observes, they represented an attempt to exert both a negative influence on the press through censorship and a positive influence by stimulating the publication of innocuous books. ${ }^{46}$

\section{Propaganda}

The difficulty of controlling pamphlets put the authorities in a dilemma, which was articulated by an English parliamentarian pamphlet of 1849: "if our adversaries write all ... and we nothing at all, the conquering sword will be conquered by the pen." 47 In effect, as the seventeenth century progressed, the pen did conquer the sword as a political weapon and the influence of oppositional pamphlets forced monarchs and the aristocracy to reconquer public opinion continually with counterpropaganda. ${ }^{48}$

Propaganda became the complement of censorship in the sense that it attempted to compensate for the failure of the censor to silence discordant voices. The French cardinal Richelieu, for example, created a censorship regime that prevailed in France from 1626 until the French Revolution. Richelieu desired a far more responsive, far-reaching, and effective system of political control than was available. Although he actively supported his own return to power in the early 1620s through propaganda campaigns, Richelieu continued to utilize the services of pamphleteers throughout his entire career. ${ }^{49} \mathrm{He}$ formed his own group of paid publicists in order to defend himself against the allegations of his enemies. ${ }^{50}$ In addition, he inspired the foundation in 1631 of an official newspaper, La Gazette, to which he occasionally sent items of news for inclusion. 51

Another significant example of the connection between censorship and propaganda is personified in Roger L'Estrange, who was appointed as a censor in England in 1693. Raymond describes L'Estrange as a "bloodhound ... who took pleasure in verbally flaying his enemies, 
and then chasing them into prison." L'Estrange subjected the press to extremely tight controls and punished authors, printers, and publishers for seditious libel whenever he could. ${ }^{52}$ However, he also appointed licensors, granted patents for official newssheets, and hired propagandists to counter critics. ${ }^{53}$

Briggs and Burke refer to L'Estrange's dual attitude as a demonstration of how governments were being forced "to contribute through journalism to the spread of a popular political consciousness which the elite generally deplored." ${ }^{54}$ Governments realized that influence was increasingly gained or lost through managing the perceptions of others. 55 Thus, for Peacey, censorship and propaganda are complementary: "Propaganda, and the engagement with the public through a broad range of literary forms, represents an attempt to restrict the boundaries of discussion and to control the terms of debate." 56

In England in the 1640s, for example, the divisions in national and parliamentary politics provided an important context for propaganda and pamphleteering, blurring the distinction between official and unofficial publications. ${ }^{57}$ Particularly from the 1640s onward, this conquest of public opinion contributed to a growing sophistication in the printing industry, represented by the growing diversity and professionalized production of pamphlets. The emergence of a parliamentary press in England in the 1640s is a striking example of this evolution, but the monarchy's reaction is equally significant. The royalist Mercurius Aulicus, one of the first important newspapers, was widely recognized as officially sponsored by the monarchy. It prompted the creation of a rival newspaper, Mercurius Britannicus, which was explicitly aimed at responding to Aucilus. ${ }^{5}$

The growing sophistication in the production of propaganda becomes evident not only by the emergence of a newspaper industry but also by the proliferation of writers who were contracted by members of Parliament and the monarchy to write pamphlets or to draft official declarations. Only some of these writers were officially recognized as propagandists. Most worked as ghostwriters or under the pretense of being independent authors. ${ }^{59}$ The commissioning of professional writers to author pamphlets by grandees in exchange for a reward became a common practice throughout Europe. ${ }^{60}$ It was assumed that pamphlets emanating from independent authors would be more credible to the public or reach a larger audience than the authors formally affiliated with those in power. ${ }^{61}$

In summary, during the early seventeenth century, royalists had to choose between engaging in propaganda through pamphlets or losing the battle for public opinion. They soon appropriated the use of the medium and discovered its possibilities for persuasion and manipulation. As Raymond notes, whereas in the 1580s the use of the pamphlet as a means of persuading readers of opinions was new and controversial, "by the 1680s it was axiomatic that an attempt to cultivate public opinion would rely on the use of pamphlets." 62

\section{Commodification}

The history of pamphleteering is also a history of commodification of print. Authors needed to recoup their costs and therefore acted as their own publishers. Pamphlets were thus sold as commodities on the market from the very onset. Pamphlet publishers were not always driven by commercial intentions. Some authors, writing for sectional interest groups or political and religious causes, were driven by altruistic motives. The vast majority of authors, however, were publishing with at least the promise of financial gain. ${ }^{63}$ 
For example, in writing about the period of the Fronde in France, Vittu states that the use of printed materials was the response to a political demand. ${ }^{64}$ However, as Carrier observes, almost all sources agree that the virulent pamphlet campaigns that opposed different political interest groups were also inspired by another important motive-namely, financial gain. In times of crisis, Carrier adds, libels sold well, offering a welcome source of extra income for those who could master the pen. 65 A detailed analysis of the economy of the distribution of pamphlets in the Dutch context, in turn, shows how, in times of turbulence, when sales of common goods decreased, the number of hawkers selling pamphlets increased because they were seeking alternative sources of revenue. ${ }^{66}$

The commercialization of pamphlet production and trade affected content. It not only led to an increase in the production of topical pamphlets for entertainment but also had an effect on the quality of political pamphlets. Information, Dooley observes, "was often modified for pure entertainment purposes." 67 The effects included mediocrity, because not all authors were politically or literarily trained; sensationalism, because accounts of conflict and disaster were popular literature; vulgarity, in the sense that libel and slander were popular with many readers; inaccuracy, because fact-checking was difficult and not a priority; and plagiarism, as (parts of) pamphlets could be recycled without reference or reward.68

Even though most pamphlet authors were educated members of the "middling sort," the pecuniary motives of authors and the wanting quality of a significant portion of pamphlet production provided ready-made criticisms for royalists and other opponents of pamphleteering. ${ }^{69}$ Raymond observes that in "the late sixteenth and early seventeenth century a stereotypical pamphleteer was an idle exploiter of the credulous vulgar; by the mid-seventeenth century he would cease to be merely frivolous and become greedy and malicious."70

It would be erroneous to analyze the commercialization of the book trade only at the individual author's level. Authors of serious books were aware of the effects of commercialization on the printing trade. That anonymous purchasers and readers displaced aristocratic patrons as the consumers and arbiters of taste and success provoked anxiety. Authors of serious books started to complain that "contemptible trashy pamphlets sold better than their best intellectual labors." 71 It is in this context that the seventeenth-century poet Samuel Butler sardonically describes the newsmonger as "a retailer of rumor, that takes up upon trust, and sells as cheap as he buys." For the newsmonger, Butler continues, news is a

perishable commodity, that will not keep: for if it be not fresh it lies upon his hands and will yield nothing. True or false is all one to him ... for that does not make it more or less news; and, if there be any difference, he loves the bad best, because it is said to come soonest; for he would willingly bear his share in any public calamity, to have the pleasure of hearing and telling it. ${ }^{72}$

Nevertheless, the commercialization of pamphlets also had positive effects. First, it contributed to a new culture of reading that was individual and far less elitist. Second, it supported a significant increase the availability and accessibility of print. The commoditization of print provided the necessary sources of income for the book trade, proving instrumental to its development. ${ }^{73}$

In England, for example, from 1641 onward, a new genre of pamphlets emerged in the markets: news books and periodic publications containing accounts of the weekly political and other 
events. Along with printed petitions and broadsides, these news books sold for as little as a penny. ${ }^{74}$ The emergence of early forms of newspapers in the Netherlands took place even earlier. ${ }^{75}$ In this way, through commodification, news that was previously available to only a few now became available to many.

Within this commercialized context, authors of political pamphlets were motivated by a variety of considerations, including pecuniary profit, personal safety, and political principles. These motives could be combined in different ways and led to a range of different kinds of relationships between authors and patrons. Authors had several possibilities for publishing their writings. Very few authors wrote solely out of principle, and most always relied on some commercial enterprise for distribution. ${ }^{76}$

Most authors of political pamphlets could indeed "not afford to ignore matters of personal fortune in order to adhere giddily to personal principles." 77 They had to self-finance their publications or rely on the printer to take the financial risk and act as publisher. Others worked as professional writers, offering their services to patrons in exchange for a financial reward. The development of propaganda as a professional machinery further contributed to authors' reluctance to serve their paymasters without remuneration and as a consequence, some pamphlets were officially subsidized..$^{78}$ Despite the growing commercialization of the pamphlet trade and the professionalization of authorship, there remained a certain allegiance to political principles. Just as with publishers, very few shifted between factions or political sides in exchange for remuneration. ${ }^{79}$

\section{Epilogue}

The viewpoints of Robert L'Estrange and his successor Robert Atkyns, as "Licenser and Surveyor" of the press under Charles II in England, further illustrates the relationship between commerce and politics. Pamphlets were used in preparing the return of the monarchy to Britain in 1660. However, once Charles II was in power, pamphlets were again perceived as a threat. Neither L'Estrange nor Atkyns thought that the existing law was sufficiently severe. In particular, they observed that the commercial basis of the book trade clashed with the royal prerogative. The book trade, they argued, was too much of an interested party, which profited more from dissident publications than from innocuous ones. ${ }^{80}$

In the Netherlands, the government faced "organized protest" from the book industry when a government commission was convened to investigate reinstating censorship mechanisms. The critique that emanated from the book industry in the three main cities, Amsterdam, Rotterdam, and Leiden, was largely similar. The book trade reacted by arguing that reverting to censorship would be harmful for trade, the arts, and the sciences. It would restrict the intellectual liberty of political and religious minorities and therefore infringe on the constitution of the republic. ${ }^{81}$

In 1688, England saw the end of the system of licensed print monopolies. With the overthrow of the Stuarts that year, the monarchy definitively lost the authority to impose licensing. For a while, licensing continued under parliamentary control. Divisions of opinion about what ought to be censored increased, while consensus grew that the publishers' monopoly hindered competition's ability to bring down prices. When licensing lapsed in 1695, it was never renewed. 82

In the meantime, the market for news rapidly expanded and some of the first newspapers emerged out of the trade in pamphlets, as "serial news books." Initially they were printed, 
published, and distributed in the same way as pamphlets, but their means of production and distribution soon became distinct from the pamphlet trade. 83 The newspaper gradually replaced the pamphlet as a model for the efficacy of print. During the first half of the eighteenth century, pamphlet production decreased and, gradually, newspapers replaced pamphlets as a source of opinion. 84

\section{Conclusion}

Throughout the seventeenth century, pamphlets came to play a dominant role in political life, both as instruments of propaganda and of resistance. The religious and political functions of pamphlets, as shaped by the political and cultural constellation of the early seventeenth century, were reflected in their style, which initially was often slanderous and seditious. This can partly be explained by the lack of a tradition of informed, rational debate and communicative ethics, but certainly also reflects the tense nature of the underlying social conflicts. Pamphlets emerged as a tool of resistance against the Catholic Church and the absolute monarchy. They were primarily designed and used to defend the interests of the emerging religious and bourgeois classes.

The history of pamphleteering prefigures a transition from a coercive to a hegemonic system, a system in which social discipline is achieved through persuasion rather than by force and in which the media play a key role in shaping public perceptions. In origin, pamphlets were certainly not a forum for the ethical articulation of rational arguments. Pamphlets were initially an arena for the conquest of public opinion. However, as these conflicts began to settle, the emergent new classes gained institutional control and new balances of power were established. Towards the end of the seventeenth century, the tone of political pamphlets began to soften, and more argumentative and informative forms of communication gained importance.

The history of pamphlet regulation follows this pattern. At first, the incumbent regime reverted to the known tools of censorship in an attempt to ban pamphlets from the political scene and restore the old order. When censorship proved largely ineffective, the authorities tried to appropriate the new medium by using it as a weapon of propaganda. In order to enforce this dual regulatory regime, the authoritarian state engaged in a coalition with the industry, leaving it to the industry to play watchdog over the content of pamphlets within the confines of legislation. That legislation, rather stringent at first, was gradually relaxed as new balances of power induced by industrialization and parliamentarianism became more established.

The history of pamphlet regulation thus illustrates how the role and function of the press in the seventeenth century coincided with more profound societal transformations. Indeed, by the end of the seventeenth century, economic and political balances of the ancient regime shifted. The emergent bourgeois class of intellectuals, liberal professions, and entrepreneurs-which included printers and publishers - represented a power to be reckoned with. In the meantime, relations between monarchy and aristocracy on the one hand, and the bourgeoisie on the other, became much less conflictual.

The commodification of the printing press in the hands of the rising bourgeoisie proved to be a stronger weapon than the repressive media regime. As the balance of power in society changed and the interest of the old and the new ruling classes gradually began to converge, an institutional reversal in the organization of press regulation emerged in the seventeenth century. In the old system, through censorship, political rule had preeminence over economic rule. Under the new regime, market rules became the primary form of media regulation, and 
political regulation became marginal insofar as the media market could be relied upon to support the hegemony of dominant classes.

The hegemonic media regime that emerged in the seventeenth century was partial in the sense that it represented the interests only of the aristocracy and bourgeoisie, and would soon face fierce opposition from the working classes. Power relations would consequently have to be renegotiated and adapted, including in the media. However, the contours of the hegemonic media system as a regulatory regime, with the consolidation of coincidental economic and political interests drawn up in the seventeenth century, would remain persistent.

${ }^{1}$ This article is based on research funded by the Research Foundation-Flanders (FWO).

2 Pascal Verhoest is Professor of Political Economy of Communication at the Free University of Brussels (VUB) and Research Manager of the research centre for Culture, Emancipation, Media and Society (CEMESO-VUB).

${ }^{3}$ See, for example, Asa Briggs and Peter Burke, A Social History of the Media (Cambridge: Polity Press, 2009); Paul Starr, The Creation of the Media (New York: Basic Books, 2004).

${ }^{4}$ Craig E. Harline, Pamphlets, Printing, and Political Culture in the Early Dutch Republic (Dordrecht: Martinus Nijhoff, 1987); Jeffrey K. Sawyer, Printed Poison: Pamphlet Propaganda, Faction Politics, and the Public Sphere in Early Seventeenth-Century France (Berkeley: University California Press, 1990); Hubert Carrier, Les Mazarinades: La presse de la Fronde (1648-1653) (Genève: Librairie Droz, 1991); Joad Raymond, Pamphlets and Pamphleteering in Early Modern Britain (Cambridge: Cambridge University Press, 2003); Jason Peacey, Politicians and Pamphleteers: Propaganda during the English Civil Wars and Interregnum (Aldershot: Ashgate, 2004).

5 See, for example, Raymond, Pamphlets and Pamphleteering in Early Modern Britain, 257.

6 See, for example, Peacey, Politicians and Pamphleteers, 303.

7 See, for example, Carrier, Les Mazarinades, 3.

8 Chantal Mouffe, On the Political: Thinking in Action (New York: Routledge, 2005), 20.

${ }^{9}$ Martin Conboy, The Press and Popular Culture (London: Sage, 2002), 11.

10 On commodification in the media, see for example Vincent Mosco, The Political Economy of Communication, 2nd ed. (London: Sage, 2009), 143-47; on media and hegemony, see Raymond Williams, Marxism and Literature (Oxford: Oxford University Press, 1977), 13-14.

11 Raymond, Pamphlets and Pamphleteering in Early Modern Britain, 44; Harline, Pamphlets, Printing, and Political Culture in the Early Dutch Republic, 25-32.

${ }^{12}$ Briggs and Burke, A Social History of the Media, 3rd ed. (Cambridge: Polity Press, 2009), 64.

${ }^{13}$ Raymond, Pamphlets and Pamphleteering in Early Modern Britain, 83; Hubert Carrier, Les Mazarinades, 163-64; Jeffrey K. Sawyer, Printed Poison, 55-56.

14 Raymond, Pamphlets and Pamphleteering in Early Modern Britain, 83-84, 91; David Zaret, Origins of Democratic Culture: Printing, Petitions, and the Public Sphere in Early Modern England (Princeton: Princeton University Press, 2000), 108; Sawyer, Printed Poison, 69; Harline, Pamphlets, Printing, and Political Culture in the Early Dutch Republic, 65.

${ }^{15}$ One of the most famous examples of such pamphlets is John Milton's Areopagitica, a transcript of a speech held in the English Parliament in 1644 in which he praises the "the liberty to know, to utter, and to argue freely according to conscience, above all 
liberties." John Milton, Areopagitica: A Speech for the Liberty of Unlicensed Printing to the Parliament of England, Project Gutenberg.

${ }^{16}$ John C. Sommerville, The News Revolution in England (Oxford: Oxford University Press, 1996), 13.

${ }_{17}$ Martin Conboy, The Press and Popular Culture, 22-25.

${ }^{18}$ Raymond, Pamphlets and Pamphleteering in Early Modern Britain, 20.

19 Ibid., 17-18.

${ }^{20}$ Marijke Meijer Drees, "Goed Voor de Ogen," in Het Lange Leven van Het Pamflet, ed. José De Kruif et al. (Hilversum: Uitgeverij Verloren, 2006).

${ }^{21}$ J. C. Nix, "Pamfletten Tussen Historieprenten," in Het Lange Leven van Het Pamflet, ed. José De Kruif et al. (Hilversum: Uitgeverij Verloren, 2006); Christi M. Klinkert, "Knokpartijen, Krant En Kunst: Oorlogsverslaggeving in Nieuwsprenten en Pamphletten Rond 1600," in Het Lange Leven van Het Pamflet, ed. José De Kruif et al. (Hilversum: Uitgeverij Verloren, 2006).

22 Raymond, Pamphlets and Pamphleteering in Early Modern Britain, 214; Sawyer, Printed Poison, 49-50.

${ }^{23}$ Raymond, Pamphlets and Pamphleteering in Early Modern Britain, 10-11; Hubert Carrier, Les Mazarinades, 105; Jeffrey K. Sawyer, Printed Poison, 50.

${ }^{24}$ Carrier, Les Mazarinades, 3-4.

${ }^{25}$ Andrew Pettegree, The Invention of News: How the World Came to Know about Itself (New Haven, CT: Yale University Press, 2014), 6.

26 Zaret, Origins of Democratic Culture, 17.

27 Sawyer, Printed Poison, 26; Briggs and Burke, A Social History of the Media, 69-79; Raymond, Pamphlets and Pamphleteering in Early Modern Britain, 145.

${ }^{28}$ Briggs and Burke, A Social History of the Media, 68.

${ }^{29}$ Raymond, Pamphlets and Pamphleteering in Early Modern Britain, 100; Harline, Pamphlets, Printing, and Political Culture in the Early Dutch Republic, 146-49; Sawyer, Printed Poison, 26.

30 Zaret, Origins of Democratic Culture, 44-67.

${ }^{31}$ Briggs and Burke, A Social History of the Media, 52.

${ }^{32}$ Harline, Pamphlets, Printing, and Political Culture in the Early Dutch Republic, 111.

33 Sawyer, Printed Poison, 58; Joad Raymond, Pamphlets and Pamphleteering in Early Modern Britain, 70.

${ }^{34}$ Carrier, Les Mazarinades, 150.

35 Sawyer, Printed Poison, 26.

${ }^{36}$ Harline, Pamphlets, Printing, and Political Culture in the Early Dutch Republic, 111-33; Otto Lankhorst, "Newspapers in the Netherlands," in The Politics of Information in Early Modern Europe, ed. Brendan Dooley and Sabrina A Baron (New York: Routledge, 2001), 155-56.

37 Sawyer, Printed Poison, 14, 18, 25; Raymond, Pamphlets and Pamphleteering in Early Modern Britain, 13, 66-69, 157, 196-97; Harline, Pamphlets, Printing, and Political Culture in the Early Dutch Republic, 111-26.

38 Carrier, Les Mazarinades, 299-312; Raymond, Pamphlets and Pamphleteering in Early Modern Britain, 154, 197; Harline, Pamphlets, Printing, and Political Culture in the Early Dutch Republic, 127-30.

39 Raymond, Pamphlets and Pamphleteering in Early Modern Britain, 67; Sawyer, Printed 
Poison, 24-25.

40 Andrew Pettegree, The Book in the Renaissance (New Haven: Yale University Press, 2010), 259.

${ }^{41}$ Arblaster, Paul. "Policy and Publishing in the Policy and Publishing in the Habsburg Netherlands: 1565-1690," in The Politics of Information in Early Modern Europe, ed. Brendan Dooley and Sabrina A Baron (New York: Routledge, 2001), 181.

42 Sabrina A. Baron, "The Guises of Dissemination in Early Seventeenth Century England: News in Manuscript and Print," in The Politics of Information in Early Modern Europe, ed. Brendan Dooley and Sabrina A Baron (New York: Routledge, 2001), 42.

43 Jeffrey K. Sawyer, Printed Poison, 18; Jason Peacey, Politicians and Pamphleteers, 163, 202. 44 Peacey, Politicians and Pamphleteers, 165-67; Raymond, Pamphlets and Pamphleteering in Early Modern Britain, 154, 196-97.

45 Starr, The Creation of the Media, 28.

46 Peacey, Politicians and Pamphleteers, 132.

${ }^{47}$ Cited in Peacey, Politicians and Pamphleteers, 37.

48 Peacey, Politicians and Pamphleteers, 31-32; Harline, Pamphlets, Printing, and Political Culture in the Early Dutch Republic, 131-32.

${ }^{49}$ Sawyer, Printed Poison, 138-39.

${ }^{50}$ Jean-Pierre Vittu, "Instruments of Political Information in France," in The Politics of Information in Early Modern Europe, ed. Brendan Dooley and Sabrina A Baron (New York: Routledge, 2001), 165.

${ }^{51}$ Briggs and Burke, A Social History of the Media, 72; Vittu, "Instruments of Political Information in France," 166.

52 Raymond, Pamphlets and Pamphleteering in Early Modern Britain, 324.

${ }^{53}$ Ibid., 156-57, 324.

${ }^{54}$ Briggs and Burke, A Social History of the Media, 76.

55 Sawyer, Printed Poison, 15.

56 Peacey, Politicians and Pamphleteers, 331-32.

57 Ibid., 58.

58 Ibid., 190.

${ }^{59}$ Ibid., 202.

${ }^{60}$ Brendan Dooley, "News and Doubt in Early Modern Culture," in The Politics of Information in Early Modern Europe, ed. Brendan Dooley and Sabrina A Baron (New York: Routledge, 2001), 278.

61 Peacey, Politicians and Pamphleteers, 60, 185.

62 Raymond, Pamphlets and Pamphleteering in Early Modern Britain, 330.

63 Peacey, Politicians and Pamphleteers, 132; Harline, Pamphlets, Printing, and Political Culture in the Early Dutch Republic, 101.

${ }^{64} \mathrm{Vittu}$, Instruments of Political Information in France, 174.

65 Carrier, Les Mazarinades, 3.

${ }^{66}$ Jeroen Salman, "Het Nieuws Op Straat," in Het Lange Leven van Het Pamflet, ed. José De Kruif et al. (Hilversum: Uitgeverij Verloren, 2006), 59.

67 Dooley, "News and Doubt in Early Modern Culture," 278.

${ }_{68}$ Marijke Meijer Drees, “Goed Voor de Ogen," 142.

${ }^{69}$ Carrier, Les Mazarinades, 4.

70 Raymond, Pamphlets and Pamphleteering in Early Modern Britain, 10-11. 
71 Ibid., 94.

72 Samuel Butler, 'A News-Monger'. In The Genuine Remains in Verse and Prose of Mr. Samuel Butler, Author of Hudibras, ed. R. Thyer (London: 1759), 2:296.

${ }^{73}$ Carrier, Les Mazarinades, 2, 295.

${ }^{74}$ Michael Mendle, "News and the Pamphlet Culture of Mid-Seventeenth-Century England," in The Politics of Information in Early Modern Europe, ed. Brendan Dooley and Sabrina A Baron (New York: Routledge, 2001), 57.

75 Otto Lankhorst, "Newspapers in the Netherlands in the Seventeenth Century," in The Politics of Information in Early Modern Europe, ed. Brendan Dooley and Sabrina A Baron (New York: Routledge, 2001), 151.

76 Peacey, Politicians and Pamphleteers, 300; Carrier, Les Mazarinades, 9-10; Femke Deen, David Onnekink, and Michiel Reinders, "Pamphlets and Politics: Introduction," in Pamphlets and Politics in the Dutch Republic, ed. Femke Deen et al. (Leiden: Brill, 2011), 20-21.

77 Peacey, Politicians and Pamphleteers, 301.

78 Raymond, Pamphlets and Pamphleteering in Early Modern Britain, 57.

79 Peacey, Politicians and Pamphleteers, 302.

80 Raymond, Pamphlets and Pamphleteering in Early Modern Britain, 326.

81 Sofie Cerutti, "De Socratische Oorlog," in Het Lange Leven van Het Pamflet, ed. José De Kruif et al. (Hilversum: Uitgeverij Verloren, 2006), 90-93.

82 Starr, The Creation of the Media, 35.

83 Raymond, Pamphlets and Pamphleteering in Early Modern Britain, 101; Zaret, Origins of Democratic Culture, 185.

${ }^{84}$ Rutger De Graaf and José De Kruif, "Schieten Met Papieren Schroot," in Het Lange Leven van Het Pamflet, ed. José De Kruif et al. (Hilversum: Uitgeverij Verloren, 2006), 97-98.

\section{Bibliography}

Arblaster, Paul. "Policy and Publishing in the Habsburg Netherlands: 1565-1690." In The Politics of Information in Early Modern Europe, edited by Brendan Dooley and Sabrina Baron, 17998. New York: Routledge, 2001.

Baron, Sabrina A. “The Guises of Dissemination in Early Seventeenth-Century England: News in Manuscript and Print." In The Politics of Information in Early Modern Europe, edited by Brendan Dooley and Sabrina Baron, 41-56. New York: Routledge, 2001.

Baron, Sabrina A., and Brendan Maurice Dooley. The Politics of Information in Early Modern Europe. London: Routledge, 2001.

Briggs, Asa, and Peter Burke. A Social History of the Media: From Gutenberg to the Internet. Cambridge: Polity Press, 2009.

Butler, Samuel, and Robert Thyer. The Genuine Remains in Verse and Prose of Mr. Samuel Butler. London: printed for J. and R. Tonson, 1759.

Carrier, Hubert. Les Mazarinades: La Presse De La Fronde (1648-1653). Genève: Librairie Droz, 1991.

Conboy, Martin. The Press and Popular Culture. London: Sage, 2002. 
Deen, Femke, David Onnekink, and Michiel Reinders. "Pamphlets and Politics: Introduction." In Pamphlets and Politics in the Dutch Republic, edited by Femke Deen, David Onnekink, and Michael Reinders, 3-30. Leiden: Brill, 2011.

Dooley, Brendan. "News and Doubt in Early Modern Culture; or, Are We Having a Public Sphere Yet?" In The Politics of Information in Early Modern Europe, edited by Brendan Dooley and Sabrina Baron, 275-90. New York: Routledge, 2001.

Harline, Craig E. Pamphlets, Printing, and Political Culture in the Early Dutch Republic. Dordrecht: Martinus Nijhoff, 1987.

Lankhorst, Otto. "Newspapers in the Netherlands in the Seventeenth Century." In Pamphlets and Politics in the Dutch Republic, edited by Femke Deen, David Onnekink, and Michael Reinders, 151-59. New York: Routledge, 2011.

Mendle, Michael. "News and the Pamphlet Culture of Mid-Seventeenth-Century England." In Pamphlets and Politics in the Dutch Republic, edited by Femke Deen, David Onnekink, and Michael Reinders, 57-79. Leiden: Brill, 2011.

Mosco, Vincent. The Political Economy of Communication. Los Angeles: Sage, 2009.

Mouffe, Chanta. On the Political: Thinking in Action. New York: Routledge, 2005.

Peacey, Jason. "Politicians and Pamphleteers: Propaganda during the English Civil Wars and Interregnum." Aldershot: Ashgate, 2004.

Pettegree, Andrew. The Book in the Renaissance. New Haven, CT: Yale University Press, 2010.

- - - The Invention of News: How the World Came to Know about Itself. New Haven, CT: Yale University Press, 2014.

Raymond, Joad. Pamphlets and Pamphleteering in Early Modern Britain. Cambridge: Cambridge University Press, 2003.

Sawyer, Jeffrey K. Printed Poison: Pamphlet Propaganda, Faction Politics, and the Public Sphere in Early Seventeenth-Century France. Berkeley: University of California Press, 1990.

Sommerville, John C. The News Revolution in England. New York: Oxford University Press, 1996.

Starr, Paul. The Creation of the Media: Political Origins of Modern Communications. New York: Basic Books, 2004.

Vittu, Jean-Pierre. "Instruments of Political Information in France." In Pamphlets and Politics in the Dutch Republic, edited by Femke Deen, David Onnekink, and Michael Reinders, 16078. Leiden, Boston: Brill, 2011.

Williams, Raymond. Marxism and Literature. Oxford: Oxford University Press, 1977.

Zaret, David. Origins of Democratic Culture: Printing, Petitions, and the Public Sphere in EarlyModern England. Princeton, NJ: Princeton University Press, 2000.

\section{$(\mathrm{Cc})$ BY-NC-ND}

Copyright (c) 2016 (Pascal Verhoest). Media Industries is an open-access, peer-reviewed, online academic journal. As such, we aim to participate in the open exchange of information. This work is licensed under a Creative Commons Attribution Noncommercial No Derivatives (by-nc-nd) License. Under this license, this work is available for sharing and noncommercial distribution provided the appropriate attribution is given. 